\title{
ACCOUNTING AND FORMS OF ACCOUNTABILITY IN ANCIENT CIVILIZATIONS: MESOPOTAMIA AND ANCIENT EGYPT**
}
IE Working Paper
WP05-21
12-05-2005

Salvador Carmona

Instituto de Empresa Business School

Calle María de Molina, 12-5

28006 Madrid (Spain)

salvador.carmona@ie.edu
Mahmoud Ezzamel

Cardiff University, Cardiff, UK ezzamel@Cardiff.ac.uk

\begin{abstract}
The aim of this paper is to identify the relevance and implications of ancient accounting practices to the contemporary theorizing of accounting. The paper provides a synthesis of the literature on ancient accounting particularly in relation to issues of human accountability, identifies its major achievements and outlines some of the key challenges facing researchers. We argue that far from being an idiosyncratic research field of marginal interest, research in ancient accounting is a rich and promising undertaking that holds the promise of significantly enhancing our understanding of the roles of accounting in organizations and society. The paper concludes by considering a number of implications of ancient accounting practices for the theorizing of accounting and identifies a number of possible avenues for future research.
\end{abstract}

- Paper to be presented to the Annual Conference of the European Accounting Association (Göteborg, Sweden). The authors are grateful to financial support provided by the CICYT research grants \# 01-0657 and SEJ-2004-08176-C02-01. 



\section{ACCOUNTING AND FORMS OF ACCOUNTABILITY IN ANCIENT CIVILIZATIONS: MESOPOTAMIA AND ANCIENT EGYPT}

Why investigate ancient accounting? During the last two decades, a growing number of publications have indirectly challenged the view that examination of accounting practices in archaic and ancient economies constitutes an antiquated exercise located at the margin of scholarly enquiry, and at worst a totally futile task of no relevance to the present (e.g., Stevelinck, 1973). Recent studies, conversely, suggests that investigation of accounting practices in ancient civilizations cast light into a number of central topics of the research agenda, involving issues in behavioural (Mouck, 2004), social (Ezzamel 1997), and accounting theory (Mattessich, 2000). Importantly for our purposes, contributions in this area span diverse issues and contexts, such as semi-barter exchange, work on state projects, taxation, and private states, in varying socio-political and economic contexts, ranging from the predominantly state-controlled economy of ancient Egypt to the less state-dominated economy of Mesopotamia. Hence, it is not entirely clear, except to those familiar with the field, what issues and contexts have been examined and what further issues should be subject of further investigation.

In this paper, we seek to identify the key attributes, scope, and implications of ancient accounting practices with a view of articulating their relevance to the contemporary theorizing of accounting. We believe that undertaking such a task is timely for several reasons. First, a considerable number of studies examining accounting in ancient civilizations have focused on the technical aspects of such practices. In contrast, our understanding of the literature we review here suggests that it offers rich insights that could have a profound impact on improving our knowledge of the roles of accounting in organisations and society and in contributing to contemporary efforts to theorise accounting (Littleton, 1968: 48). In particular, we argue that an emphasis on context embeddeness would enable us to contribute to the present debate on the role of accounting in the deployment of different forms of accountability (Ezzamel, Hoskin and Macve, 1990). Second, in addition to the diverse number of topics addressed by accounting academics, many of the contributions to this area have been made by specialists in ancient history such as assyriologists (e.g., Schmandt-Besserat, 1977, 1992; Nissen, Damerow and Englund, 1993) and egyptologists (Spalinger, 1986; Kemp, 1989). Yet, research conducted by these scholars has appeared in ancient and business history outlets (Finkelstein, 1968; James, 1968), and sometimes published many years ago (Lau, 1906; Nesbit, 1914). Arguably, the scattered nature of research in this area makes its impact on and implications for the theorizing of accounting either not being fully developed, or not being acknowledged in the main stream accounting literature.

In doing this, we acknowledge from the outset the difficulties to conduct research on ancient societies. In any research undertaking, the quality of what a researcher can do is limited by his/her own intellectual powers and the amount of evidence available, but this problem is more exacerbated in the case of ancient history (Keister, 1963). The choice is either we attempt to forge accounts of such histories, no matter how incomplete, or refrain from writing on ancient history. Finley (1992, p. 25) has lamented ancient historians who rely on anecdotes, calling for "abandoning the anecdotal technique of dredging up an example or two as if that constituted proof." While we would endorse Finley's suggestion when evidence is 
plentiful, we would disagree if all that is available as evidence is of an anecdotal nature. Even small fragments of evidence can reveal interesting insights, but a careful researcher should highlight these limitations and their implications on the findings of the study (Mattessich, 2000).

This paper is organized as follows. In the next section, we provide a discussion of the wider context of ancient economies, commenting briefly on the debate on the nature of the state and economy in the context of the ancient world. We then organize our synthesis around key aspects, such as research focus, methods of investigation used, and problems encountered by researchers (e.g. translation; lacunae in accounting data; absence of full contextual material). Using these aspects, we note the breadth and depth of each study, as well as its strengths, achievements, and limitations. In a discussion and conclusion section, we summarize the main themes emerging from our synthesis of the literature, suggest a number of topics for future investigation, and discuss the challenges facing scholars in conducting research into ancient accounting.

\section{APPROACHING THE CONTEXTS OF MESOPOTAMIA AND ANCIENT EGYPT}

We begin with the basic tenet that for the accounting practices of the ancient world to be fully appreciated and understood, they need to be located within their wider socio-political and economic contexts. In the case of Mesopotamia, for example, it would be hard to understand the rationale of operators' salaries without considering the social embeddeness of such practices. As shown by Gelb (1965), operators' compensation was usually made in kind and the amount of the annual, monthly, or daily wages of workers was contingent on gender, age, and social status ${ }^{1}$. In the case of ancient Egypt, it would be difficult to properly examine accounting practices of bakeries without considering that bread had a great symbolic significance, over and above its importance to the population at large. Bread was endowed with life-giving and sustaining power; it was the very stuff of life (Wilkinson, 1994). In this respect, Ezzamel (1997) examined an army bakery, dating to the reign of Seti I (1303-1290) who waged considerable military campaigns. In such context, the proliferation of detailed accounting practices for the bakery may have been driven by a strong incentive to ensure that army supplies of bread were monitored as carefully as possible to avoid possible shortages that may have had serious impacts on the ability of the army to wage its military campaigns. In short, researchers of the ancient world face what seems to be the intractable problem of describing and analyzing practices so remote from their contemporary eras and using

\footnotetext{
1 Monies of account in Mesopotamia and ancient Egypt were either weight or capacity measures. In Mesopotamia, weight measures included:

1 sicle approx. 8.30 grammes; 1 mine $=60$ sicles approx. 500 grammes; 1 talent $=60$ mines approx. 30 kilos (Snell, 1982).

Capacity measures included : 1 qa, approx. 0.84 litres; 1 pi = 36 qa, approx. 30 litres

In ancient Egypt, weight measures included: 1 deben, approx. 91 grammes.

Capacity measures included: 1 hin $=10$ hoipe $=40$ khar, approx. 18.17 litres.

The capacity and weight measures were intertranslatable, in the sense that the ability to combine them using equivalences. Thus, the sniw, another capacity measure, was equivalent to 5 deben, 1 hin $=1$ deben (Janssen, 1975).
} 
linguistic terms that may bear little or no resemblance to how the ancients described or understood their world. Lying at the heart of this concern is the constitutive power of language and its effect on forging a picture of the remote past; contemporary researchers may not be reproducing the past so much as re-creating it through their inscriptions.

It is a contentious issue the extent to which contemporary terms, such as 'economy' and 'market', could be used to provide sensible descriptions of ancient societies ${ }^{2}$. As far as the notion of economy is concerned, Finley (1992: 21) argues at some length that the ancients did not have a concept similar to the notion of what we now understand as "the economy":

\begin{abstract}
"[The ancients] in fact lacked the concept of an "economy", and a fortiori, they lacked the conceptual elements which together constitute what we call "the economy". Of course they farmed, traded, manufactured, mined, taxed, coined, deposited and loaned money, made profits or failed in their enterprises. And they discussed these activities in their talk and their writing. What they did not do, however, was to combine these particular activities conceptually into a unit, in Parsonian terms into "a differentiated sub-system."
\end{abstract}

Granted, there is every reason to suggest that the ancients did not develop a conceptual construct similar to that which we now call the economy, and care should be exercised when interpreting ancient practices so that they are not conflated by meanings the ancients would not have recognised. This difficulty, however, should not hamper efforts to study ancient economic and social practices, even though they may not correspond to whatever conceptual categories we nw employ. Our use of the term 'economy' as it applies to ancient societies would entail planning and conducting economic activities of the kind mentioned in Finley's quote above, but without assuming that it involved a collection of conceptual elements akin to those used today. Consequently, there is also no reason why the word economy could not be used in an ancient context, as long as they are emphasized and their meanings are differentiated from those circulating in contemporary economies.

It is within this understanding that we seek to approach our attempt to contextualise accounting practices analysed in the paper. Similarly to examination of understandings of the economy, the question of whether or not markets existed and functioned in the civilizations of the ancient Near East has attracted the attention of researchers in this field. Briefly, there are two schools of thought; one affirming the existence and importance of markets, even though researchers of this persuasion would concede that such markets did not exhibit all the characteristics associated with market mechanisms. In their views, the market would consist of a place where commodities are exchanged for a price, even though the price is paid in kind rather than in coins (Janssen, 1975; Renger, 1984).

Polanyi (1957) is perhaps the most influential writer of the school that denies the existence of markets in ancient societies. For him the market is a self-regulating mechanism that determines the interaction of supply, demand and price for specific goods or services, as evidenced in capitalist societies. In this vein, commenting on trading in the time of Hammurabi, he stated "Babylonia, as a matter of fact, possessed neither market places nor a

\footnotetext{
${ }^{2}$ See, for example, the opposite viewpoints of Miller \& Napier (1993) and Fleischman \& Tyson (1998). In the particular case of ancient accounting, the works of Mattessich (2000) exemplify the use of contemporary notions to events of the past (e.g., budgets).
} 
functioning market system of any description" (p. 16). Other researchers attested to the existence of places for markets in Mesopotamia, but either insisted on the absence of a market economy (Oppenheim, 1964), or spoke of a possible notion of a market price but then surmised that it might have been fixed by the government rather than by trade in the market (Goetze, 1956; Leemans, 1960). For this school, even when places existed for trading, they were confined spaces where only few items were exchanged in a manner that did not contribute appreciably to the livelihood of producers and sellers (Dalton, 1968).

Polanyi (1977) argued that forms of integration of the human economy are embedded in particular societal structures or contexts. He distinguishes three such forms: reciprocity, redistribution and market exchange. Reciprocity entails exchange of gifts typical of primitive societies, redistribution means allocation of goods through centralised bureaucracies that collects and redistributes, characteristic of ancient economies, and market exchange is of the kind familiar in capitalist societies. In this latter work, Polanyi refined his thoughts further by developing the notion of 'market elements' that seek to emphasise the institutional characteristics that constitute the market. These elements comprise:

\footnotetext{
"a site, physically present or available goods, a supply crowd, a demand crowd, custom or law, and, equivalences.... Whenever the market elements combine to form a supply-demand-price mechanism, we speak of price-making markets. Otherwise, the meeting of supply and demand crowds, carrying on exchange at fixed equivalences, forms a non-price-making market. Short of this we should not speak of markets, but merely of the various combinations of the market elements the exchange situation happens to represent." (ibid, p. 125).
}

For Polanyi, ports of trade, and the provisioning at the gates in what he terms 'redistributive oriental economies' exhibit market elements, but none of them, however, are markets proper, because of the absence of supply-demand-price interaction, although they still can be considered 'local markets' in this restrictive sense.

Given these refinements to Polanyi's thoughts, it can be stated with confidence that local markets as locales of exchange existed in both Mesopotamia and ancient Egypt. Evidence on the existence of markets in Mesopotamia and ancient Egypt has been cited by several writers (e.g., Janssen, 1975 for ancient Egypt and Renger, 1984 for Mesopotamia and ancient Egypt). This evidence, in the form of market scenes as well as entries of exchange, attests clearly to the existence of local markets in both societies. In these market locations, buyers and sellers met frequently to exchange items that in the main tended to be 'valued' using a money of account in order to render these different items comparable. The intervention of such money of accounting ensured that diverse commodities could be translated into a common denominator as a means of ensuring some measure of exchange reciprocity. How the prices were arrived at is difficult to attest; most likely there was no dynamic interaction of supply and demand forces to generate prices akin to those of contemporary markets. At the very least, therefore, the evidence suggests that in both Mesopotamia and ancient Egypt a number of the key elements suggested by Polanyi (but not all) were present, well defined market locales; buyers and sellers exchanging commodities at agreed prices but without coinage mediating in the exchange (since coinage was not known), and such local markets satisfied many local needs. 
The notion of the state equally applies to ancient societies. In doing this, the following conditions should be met:: a geographical area with a population and a recognised legal authority, and this applies to country states as well as city states (see Eisenstadt, 1969; Ball, 1995; Barry, 2000; Warburton, 1997 for views on this debate).

In discussing the role of the state in society and the development of economic activities in Mesopotamia and ancient Egypt, it is important to engage, albeit briefly, with the debate on the drivers and nature of economic activities. In this context, the name of Wittfogel (1963) looms large because his work cast a very long shadow over the understanding of the culture of the Orient in general and that of the ancient Egyptian economy in particular. Wittfogel's ideas had their roots in the work of Marx (quoted in d'Encausse and Schram, 1969), dubbed later as the concept of oriental despotism, which argues that the centralising power of government emerged in the Orient as an automatic response to the necessity of an economical use of water in agriculture via building canals and waterworks, that is, what Marx termed the 'Asiatic mode of production. The alternative to centralised government, in the form of voluntary associations that developed in Flanders and Italy to deal with the same problem, could not be pursued in the Orient, Marx asserts, because its civilizations were too low and territorial extent too vast compared to those of Flanders and Italy.

Wittfogel (1963) drew on this concept of oriental despotism to develop his thesis on hydraulic civilization, which claimed that the emergence of the state with centralised authority, such as that of ancient Egypt, was associated with an Asiatic mode of production, feudalism, and slavery which were used to develop irrigation systems. It did not take long for a refutations of this thesis to be advanced; Schenkel (1978, cited in Warburton, 1997, p. 40) showed that the ancient Egyptian state did not regard irrigation as a major responsibility, and was not in response to the demands of irrigation To summarise, the views of Marx and Wittfogel contend that ancient Egyptian civilization relied in its achievements on corvée labour and slavery, whereas the alternative view, which while not completely denying the presence of such forms of forced labour, would insist that private labour commanding wages, or rations, and private exchange existed side by side with the domain of the state, and those who worked for the state were not slaves but perhaps forced, but paid for, labour. In our subsequent analysis, it is this latter view that we adopt in our review of the literature on accounting in Mesopotamia and ancient Egypt.

In sum, we contend that the constitutive power of language cannot be avoided, and this applies to ancient as well as contemporary contexts. Hence, we need to move away from such a misplaced concern with what constitutes historical "proof" (Finley, 1992, p. 25) and acknowledge that there is no such a thing as a concrete history "out there" to be captured but rather histories to be written (Mattessich, 2000: 3-14). In the context of our paper, what we offer is our own account of these ancient histories via our own reconstruction of how previous researchers wrote these histories. 


\section{Mesopotamia}

During the period 8000-3700 BC the Fertile Crescent witnessed the spread of small settlements (Postgate, 1992). The economic activity in this area benefited from as the floods of the rivers Tigris and Euphrates, which enabled two bountiful harvests of cereals per year (e.g., barley and wheat), as well as provided proper conditions for the practice of cattle (e.g., goats, sheeps). In contrast to the extremely fertile land, the area lacked natural resources such as wood, stone, and precious metals and, hence, there was a solid basis for trade with neighbour regions as well as within Mesopotamia (Oppenheim, 1954). Tokens, shaped into simple geometric forms, such as cones or spheres, were used for stewardship purposes, in relation to identifying and securing a surplus for maintenance of farming communities over time, but not for trade or exchange (Schmandt-Besserat, 1982). According to Lau (1906: 4344), such examples of accounts referred to lists of personal properties. Then some time after $5000 \mathrm{BC}$ city-states began to emerge and these had treasury functions that exacted tax and tribute from the population and the tokens were developed to assist with this tax and tribute assessment and collection. These city-states had large territories and sizeable populations, with substantial land for agriculture.

The Mesopotamian civilization emerged during the period 3700-2900 BC amid the development of technological innovations that increased agricultural efficiency (e.g., plough), speeded up transportation (e.g., sailing boats), and enhanced tooling through improvements in metal working (e.g., copper) (Postgate, 1992; Maisels, 1993). As shown by SchmandtBesserat (1982), clay tablets with pictographic characters appeared in this period to record commercial transactions performed by the temples. Such records preceded the earliest found examples of cuneiform writing in the form of abstract signs incised in clay tablets (Powell, 1981: 419-420), which were written in Sumerian by 2900 BC in Djemdet-Nasr (Rivero Menéndez, 2004: 40). Therefore, what Mattessich (2000: 3) terms "token envelop accounting" not only preceded the written word but constituted the major impetus in the creation of writing and abstract counting (e.g. Schmandt-Besserat, 1977, 1992). Around 3250 $\mathrm{BC}$ tokens began to be impressed onto the damp clay before enclosure, and later complex tokens were incised on that surface with a stylus as a representation of the items deposited inside the clay envelops which were then sealed (Schmandt-Besserat, 1992). This was the means of assuring the recipient of the sealed clay envelops that the internal contents matched exactly the record impressed or incised on the external surface. In a later development, clay tablets replaced incised representations on external surfaces of sealed envelopes as a space on which accounting entries were made.

The Sumerian civilization lasted from 2900-2335 BC and featured small, rich city-states that engaged in continuous wars to resolve issues of property rights on irrigation water. By the middle of the millennium, the size of city-states reduced significantly and the small-city state model became dominant, which in turn deepened the process of division of labor within cities as well as provided a basis for the emergence of social classes and the hierarchization of society around military and religious classes (Snell, 1997). The former was lead by the royal palace, which deployed its coercive power over the population and rival cities and was invested with legitimacy before the population as long as it succeeded to maintain/expand the 
property and resources of the city-state. Although the temple had a subordinate role vis-à-vis the royal palace, it constituted an important centre of economic activity; the temple exerted extensive ownership over land and farms and had an active role in the construction of public infrastructures (e.g., irrigation channels, see Rivero Menéndez, 2004). During the Sumerian period, the clay envelops were "replaced by flat clay tablets to be impressed by tokens which then merely transferred symbols, but had no longer representative meaning on their own" (Mattessich, 2000: 4). Such documents were kept by scribes, who were carefully trained to acquire the necessary literary and arithmetic skills and were held responsible for documenting commercial transactions (Nissen, et. al., 1993).

The Old Babylonian Empire ruled during 2003-1595 BC. This period witnessed the emergence of private property in the Fertile Crescent; royal palaces and temples sold land and farms to private individuals and also engaged in extensive leasing of agricultural areas to farmers. As we shall see below, these and similar transactions were thoroughly documented in clay tablets and used monies of account as an instrument of payment (e.g., barley). Furthermore, the turbulent period of wars in this area came to a halt under the reign of Hammurabi, who deployed a centralized system of administration of public affairs. This consisted of the enactment of districts headed by governors, who replaced the local kings, not least the separation between the temple and the royal palace (Harris, 1961). Finally, Hammurabi earned a place in history through the code that bears his name and that enshrined laws addressing issues such as the property of land, commercial transactions and work.

The Middle Babylonian and Assyrian periods lasted from 1590 through 1077 BC. The former period witnessed the awakening of commercial activities between Ancient Mesopotamia and Egypt, whereas the latter featured continuous wars that ended with the supremacy of Babylonia and installed a feudal system in society. This was followed by the Middle Assyrian and Neo-Assyrian Empires (1365-612 BC), characterized by a combination of campaigns to conquer the territories of the Fertile Crescent and the building of military fortresses, hydraulic infrastructure and royal palaces. Success in military endeavors peaked with the conquer of substantial portions of Egypt, including its former capital Memphis in 671 BC, which in turn resulted in the levy of annual taxes from that kingdom (Rivero Menéndez, 2004; Pritchard, 1975).

\section{Ancient Egypt}

Broadly speaking, ancient Egyptian history has been divided by scholars into pre-dynastic and dynastic eras (Kemp, 1989; Grimal, 1992). The Dynastic era, from which the accounting literature reviewed here is drawn, is further divided into the Early Dynastic Period (3300 BC$2700 \mathrm{BC}$ ) whose dawn witnessed the unification of the two lands of Egypt into one country, the Old Kingdom (2700 BC-2200 BC); the Middle Kingdom (2050 BC-1780 BC), the New Kingdom (1552 BC-1080 BC), and the Late Dynastic Period (1080 BC-332) The latter four periods were interspersed with Intermediate Periods, each lasting a considerable number of years. Our discussion here focuses on Dynastic Egypt, where virtually all the evidence used in the literature reviewed here comes from. Although accounting and writing emerged at least two centuries before the unification of Egypt (Davies and Friedman, 1998), it was not until 
the unification of Egypt into a central state that accounting practices began to be used on a more systematic scale. Except for the intermediate periods, where Egypt was politically divided, the state played a major role in dynastic ancient Egyptian history, covering the spheres of administration, the economy, civil life, and the military. While on the surface all these periods seem to exhibit remarkable similarity, such resemblance only serves to deceive. Similarity and stability was a myth strongly promoted in formal inscriptions by ancient Egyptians to create an impression of and permanence as manifestations of social and cosmic order which they believed was essential for their survival (Assmann, 2002).

Much of the economic activities undertaken in ancient Egypt belonged to the royal, or public, domain, although there was always some scope for private activities and transactions in local markets (Janssen, 1975). ${ }^{3}$ In ancient Egypt, kingship was vested in divinity, with the Pharaoh considered a god ruling on earth on behalf of other gods in the sky. State institutions reproduced and re-affirmed this divine dimension of kingship through royal regalia, festivals, written texts, and artistic representations (Wilkinson, 1994). The Pharaoh was assisted by a Vizier (two Viziers in later Kingdoms) and a carefully organised bureaucracy with various layers of administrators and scribes, reaching down to the level of mayors in cities and towns. The scribes were trained in writing and arithmetic, and although the term 'scribe' meant 'learned person', in the main most scribes functioned as bookkeepers, and were highly regarded within the social hierarchy of ancient Egypt. Temples also played an important role in ancient Egypt, not only as places of worship that helped stabilise the right of the monarchy to the throne, but also as significant economic institutions (Janssen, 1979).

Despite the scope for private activities, it can be safely stated that most of the economic domain related to the state institutions and temples. The royal domain and the temples engaged in extremely large projects, such as building and renovating tombs, temples, palaces, royal workshops, as well as land cultivation, workshops for forging tools, bakeries and breweries, and the manufactury of textiles and metals. These activities required substantial organisation of work practices and allocation of tasks and duties, monitoring of achievements, and allocation of rations (Kemp, 1989; Quirke, 1990). A money of accounting system was developed, in the absence of coinage' that functioned as a common denominator converting baskets of different commodities into value equivalence and recording these values in accounting books. Impost (or 'tax') was assessed and levied against crops and then collected by the scribes to be stored in granaries for use as future rations to the Pharaoh's subjects, provision for the royal palace and its dependants, and to personnel attached to temples, and the workmen in the royal necropolis. While numerous changes occurred throughout the long history of ancient Egypt, concerning the extent of the divinity of the Pharaoh, the degree of centralisation/decentralisation of state power, administrative arrangements, property rights, and the scope for private economic activities, this is not the place to elaborate on these shifts, and at any rate they will be referred to in the appropriate parts of the synthesis as we see fit.

The significant role played by the state in the economy of ancient Egypt has led many writers to describe it as a 'redistributive system', that is a centrally-based bureaucracy that collected

\footnotetext{
${ }^{3}$ Of necessity, this is a broad brush and very brief statement on ancient accounting history (for a more detailed discussion see for example Kemp, 1989; Grimal, 1992; Trigger, 1993; Assmann, 2002)
} 
from its subjects only to redistribute to them later (e.g. Janssen, 1975). Although there is considerable debate as to the level of significance of each of the public and private spheres of the ancient Egyptian economy (contrast for example Janssen, 1975, Kemp, 1989, and Warburton, 1997) where some would argue that the private sphere was quite minimal within the Egyptian economy while others accorded it a much more significant role, the important point to note is that both spheres did exist and their economic activities are manifest in our subsequent discussion.

The scribes played an active role in the economic activity of the age. They were highly esteemed, and typically well rewarded, learned men (although there were a few women scribes) who primarily performed all writing and record-keeping, including accounting entries. They were well trained in writing texts and business letters arithmetic, and were equipped with a specially designated vocabulary for the use in record-keeping (James, 1968; Janssen and Janssen, 1990).

\section{ACCOUNTING AND ACCOUNTABILITY IN MESOPOTAMIA}

Research on accounting in Mesopotamia owes a great debt to the pioneering work of Schmandt-Besserat $(1977 ; 1978 ; 1979 ; 1980 ; 1981 \mathrm{a} ; 1981 \mathrm{~b} ; 1983 ; 1984 \mathrm{a} ; 1984 \mathrm{~b} ; 1986 \mathrm{a}$; 1986 ; 1 1992; 1997) on the origins of accounting, counting and writing. As indicated above, her path-breaking work demonstrated that token accounting was invented before both abstract counting and writing. The accounting scholar with the most prolific publications on the subject is Mattessich $(1987,1989,1991,1994,1998$ a, 1998b, 2000), whose work is reviewed in detail below (see table 1).

In the $4^{\text {th }}$ millenium B.C., Mesopotamian scribes assigned tokens of different shapes to different commodity accounts. Mattessich (1987), following the lead of Schmandt-Besserat, notes that a sealed envelop containing tokens inside and impressions of the same tokens on the outside surface could have functioned as a personal account of a steward or debtor as well as an inventory list of his investments. Simple tokens were used for such items as grain and cattle whereas more incised and perforated tokens recorded services and manufactured items. This finding was supported by an envelope discovered in the 1920s (Schmandt-Besserat, 1992: 8). The counters represented small cattle and was signed by the shepherd:

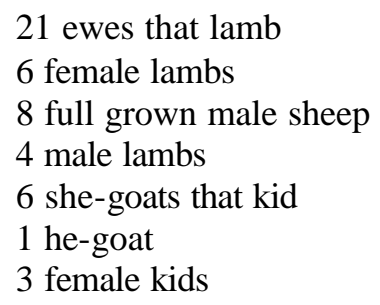

Mattessich (1987) stresses the dual significance of these tokens; being both a set of individual assets in their detail and a representation of equity in their totality. This early accounting was capable of monitoring obligations and levies from stewards and tax payers and recording the actual payments in kind by debtors. He then argues that not only is every piece of commercial 
reality (such as a jar of oil) correspond to a specific token, but also the relations (such as property rights) had proper correspondence through the location of certain tokens in a particular aggregate.

By the middle of the $4^{\text {th }}$ millenium B.C., the scribes started impressing the image of the tokens directly into solid clay tablets, which in turn would lead to the "obsolescence of clay envelopes and tokens" (Mouck, 2004: 107). Almost without exception, these tablets simply list numbers or quantities of items or commodities, without reference to their purpose or context. In commenting on the clay tablets of the fourth millennium, Nissen et. al. (1993: 35) note how the level of details contained in these tablets varied according to the administrative level, with the degree of detail being greater for higher administrative levels compared to lower administrative levels.

Nissen et. al. provide evidence on accounting for various domains, one of which relates to Kushim, either an official or an institution (the meaning rendered is not exact) responsible for a storage facility for the ingredients required for beer brewing (malt and cracked barley or barley groats). The tablets recording these activities specified the amounts of the product, its quality, location, or connected responsibility for a given period. As barley left the granaries of Kushim for processing, the quantities were added up, with each entry quoting the title of the official and signed by both Kushim and the official, thereby locating responsibility for the allocated barley in that official. The amounts of barley were differentiated by type as to whether they were barley groats or malt, the individual quantities of each type were then aggregated into a total for each type, before these two totals were finally aggregated into a grand total of barley groat and malt. In another tablet, the scribe noted the exact ingredients required for nine different cereal products and eight different kinds of beer in a tabular format. As this tablet was unsigned, Nissen et. al. (p. 43) have suggested that it was "some sort of supplementary annotation to the proper administrative document." Finally, the actual beer produced was recorded, as well as the names of the persons who received the beer, with the possibility that, Nissen et. al. (p. 46) surmise, labour time required for beer production was recorded. The detailed analysis of Mesopotamian accounting provided by Nissen et al. (1993: 21) reaffirm Schmandt-Besserat's argument that token accounting preceded writing.

The accounting contents of the tablets became more meaningful with the evolution of writing, as language-related designations began to be added to the entries to clarify the function of records and their relationships. Nissen et. al. (p. 47) point out: "Whereas during the archaic age [3000 B.C.] the addition of further information concerning product quantities was restricted to placing a numerical sign at a predetermined place within the text format, such information was incorporated into grammatically structured sentences in later Old Sumerian texts from pre-Sargonic Lagash [2500-2300 B.C.]"

The entries kept in the tablets were recorded at the moment of the transaction. According to Rivero Menéndez (2004: 283), it was customary to call the scribe to the temple, palace, or private domain to record commercial transactions, irrespective of their volume. Mesopotamians had a tradition of keeping physical accounts of transactions, which were signed up by the parties, witnesses and the scribe (Chatfield, 1977: 5). Since the archaic period, the name of the debtor was identified through his seal on the envelope (Schmandt- 
Besserat, 1978). The following tablet, which depicts a lease of cattle, illustrates the procedure and care for details of such transactions (Finkelstein, 1968):

92 ewes that lamb

20 he-goat

22 she-lambs that kid

24 full grown male sheep

33 she-goats

4 full grown male goat

27 she-goats that kid

Total 158 lambs, 64 goats

That Sin-Samuh trusts Dada the shepherd.

He will be held responsible for them and will replace any lost animal.

If Nidnatum, his assistant, escapes, he will be held responsible for that.

Dada will pay 5 gur of grain. (Three witnesses. $18^{\text {th }}$ day of the $4^{\text {th }}$ month,

Samsu-iluna, year 1).

Some tablets from the later Old Sumerian period detail bread baking, where a specific amount of bread is listed against the specification of its cereal ingredients, depending on quality as reflected in a production rate for a given type of bread. Other tablets included entries for bread and beer rations and the ingredients required to make them. These tablets began by listing the names of individuals with the largest rations followed by those with smaller rations. At the end of the tablet, the amounts of bread and beer are totalled by type and the grand total for the flour and barley used was also recorded. The tablets were dated daily, and the scribes showed how the amount of flour corresponded exactly to the amount actually used in baking the bread, and the same applied to barley and beer, leading Nissen et. al. (1993, p. 49) to suggest that this checking of actual against theoretical amounts was "Perhaps the most important accounting operation introduced during the third millennium B.C." As shown in the case of Kushim, these bookkeeping procedures can be traced back to the archaic period, but it is not clear when the systematic comparisons of theoretical and actual amounts began. Deficits in one year, arising from shortage of actual amounts compared to theoretical amounts, were carried forward to the following year and were liable to later reimbursement. Therefore, the use of "'theoretical' amounts in the form of future calculations, debit posts, standardised obligation, and similar nonempirical accounting procedures" made Mattessich (1998: 35) invoke the contemporary term 'budgetary procedures' when discussing these tablets and, ultimately, suggests the existence of ancient cases of human accountability.

Nissen et. al. (1993) then argue that, by 2100 B.C. (Ur III), accounting for theoretical (expected) and actual performance reached its most developed form. From then onwards, the entries record labour performance, along with theoretical credits and duties. The balancing of expected and actual labour performance was recorded at regular intervals for the foremen of the state-controlled labour force, using an accounting period of a 12-month-year, with each month being 30 days long, a time conception that corresponds exactly to that of ancient Egypt. Balances were carried forward to next periods; most frequently the balances were deficits (overdrawn) as the expected performances seem to have been "fixed as the maximum of what a foreman could reasonably demand of his workers" (p. 49). Such balancing periodic 
entries were underpinned by some measure of standardisation of performance and a value equivalence system: "A precondition for the feasibility of such global balancing of all expected and real performances
was the standardization and calculability of the expected performances, as well as a means of
comparing all performances. Because the economy of the Ur III period was still based
predominantly on natural payment and exchange, an innovation was required for the realization of
such control through a statewide recognized system of accounting. The introduction of unifying
norms of performance and a system of value equivalence was in fact the consequence by which the
normed natural performance became comparable to each other. Although we are often only able to
trace the performance standards and value equivalences through calculation of account entries,
there can be no doubt of the existence of explicitly formulated norms which were strictly adhered
to. They can be reconstructed from conversions of labor performances and products into
equivalent products specific to the respective centre of the economic organization. Depending on
the economic sector, the means of comparison or the measure of standardized norms and duties
could be silver, barley, fish or 'laborer-days', that is, the product of the number of workers by the
number of days they worked. The reconstruction of the conversions established the fact that they
were based on specified conversion factors for different labor performances and produced goods."
(Nissen, et. al., 1993, pp. 49-51)

A considerable amount of the surviving accounting records during Ur-III refers to the temples and their role in agriculture. The records traced the expenses incurred in farming the land, such as fodder of oxen, tooling, and compensation paid to labourers in barley, clothing, and silver, as well as the concomitant performance of land (Rivero Menéndez, 2004: 300)

The organization of the accounting texts of this era can be illustrated by reference to a more complete account of female labour (Nissen et al., 1993: 52-54). The top left-hand of the obverse side contains entries of debit balance carried forward from the previous period, and the expected (theoretical) performance for the current period, with the aggregate of these two items clearly written. The lower part of the left-hand and the whole right-hand of the obverse side have entries showing credits as amount of delivered flour, converted into female workdays, and other labour performance by the female labour force. The reverse side contains other credit entries, the aggregation of all performed labour as credit, and the final balance to be carried forward for the next period. In commenting on how these remaining balances were traced, Nissen et. al. (p. 54) state:

"From other texts we know what drastic consequences such continuous control of deficits meant for the foreman and his household. Apparently the debts had to be settled at all costs. The death of a foreman in debt resulted in confiscation of his possessions as compensation for the state. One consequence of such a confiscation was that the remaining members of the household could be transferred into the royal labor force and required to perform the work formerly supervised by the deceased foreman."

There is a significant amount of evidence concerning the distribution of rations and organization of labour, although as expected the level of detail improves as we move from the archaic period to the Old Sumerian era. The archaic evidence simply shows names of workmen and entries of rations, equivalent to 0.8 liter of grain per workman daily irrespective 
of the workman's particular employment, which approximates the minimum level of subsistence, and this figure remained virtually the same throughout the third millennium B.C. (Rivero Menéndez, 2004: 195-197). Workmen were organized into gangs of 10 each plus a foreman and their rations were delivered to them through a chief supervisor. It is not until the Old Sumerian period (2450 B.C.) that the first evidence on calculation of expected work performance emerges, which quantified work duties, e.g. the amount of barley a labourer had to harvest, or the amount of soil that had to be excavated in a workday. Levels of expected performance varied according to the sex and age of the labourer. Accounts of a grain processing workshop reveal detailed measures of control at work for 36 female labourers and entries made for each day of the month, for several months. Furthermore, during Ur-III, Rivero Menéndez (2004: 291) reports cases of strict control over sick labourers, with details about payments made to absentees and names of those that replaced them. At the same time there are traces of records of raw and finished products recorded, and the finished products converted into the standard value unit of barley. Such conversion ratios were fairly stable over time, leading Mattessich (1998, pp. 14-15) to surmise "These fixed conversion ratios may also have fulfilled a function similar to transfer prices so important in an economy of regulated and manipulated values." The entries also record the labour time of the millers to an exactness of $10 / 60$ of a work-day in the total balance. The balance shows the difference between raw materials and labour force expressed in labourer days at the end of an accounting period against real delivered products and the work actually performed, and any deficits had to be cleared directly (Nissen, et. al., pp. 83-84).

Further evidence from the administration of fields attests to the use of length measures to calculate areas in order to determine the amount of grain seeds required to sow a particular filed, which typically cam from central grain supply administered by large granaries (Powell, 1984; Maekawa, 1990). Farmers calculated the distance between seeds, the number of furrows to be deployed in a given area and the amounts of grain required to plow and sow a particular field. During the Ur-III period, for example, the stand ard was 10 furrows per nindan $^{4}$ (Rivero Menéndez, 2004: 123). On this basis, farmers estimated the distance that oxen had to cover and, hence, the necessary amount of fodder. As a result of these standards, figures on the obverse of a tablet typically represented the grain needed to sow the filed area stated on the reverse of the tablet, and these tended to be accompanied by entries of the name or title related to the activity/field.

The production of the land was recorded and measured with criteria similar to those of human performance. The following tablet from Ur-III shows the crop of a date palm plantation in gur or $q a$, whose breakdown comprises groups of palms (Myhrman, 1910: 63-65). Interestingly, control over production extends towards such palms whose dates were robbed:

7 date palms, 1 gur each.

2 trees, 249 qa each.

12 trees, 180 qa each.

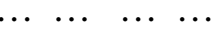

40 date palms, whose dates have been stolen.

Total: 190 date palms cropped.

\footnotetext{
${ }^{4}$ Approximately 60 centimeters between rows.
} 
Total: 40 date palms stolen.

Total: 44 gur 180 qa of dates.

Mes Shu-kul $\left(4^{\text {th }}\right)$ day.

Year in which the country Zaba-ali was devastated.

( $7^{\text {th }}$ year $)$

The sets of accounts also referred to animal husbandry. For example, there were estimates of offspring for bovine cattle over a 10-year window (Rivero Menéndez, 2004: 292). In particular, a document of the Old Babylonian period shows a lease contract of cattle establishing that 100 lambs should produce 80 offsprings in a year and makes provisions for death animals and standards of wool that should be produced over such period (Stol, 1985).

In the archaic period, texts record compilation of flocks differentiated by type and sex, and amounts of 'dairy fat' (Nissen et al., 1993: 92-95). They comment that "The modalities by which the processing of animal products was organized complied with the centralized structure of the administration of livestock herds itself' (ibid, p. 93). In the Old Sumerian period, cheese delivery quotas of herdsmen in charge were recorded, using jars with standardized liquid capacity as measures (the traditional grain measures), in contrast to archaic times when cheese was counted in discrete units (ibid, pp. 96-97). Cattle breading was also accounted for, and the authors cite a document which calculated annual production of 'dairy fat' and cheese for four milk cows over ten years. This document does not appear to be a record of actual activities, but rather a theoretical calculation of expected reproduction of consecutive generations of cows. The text assumes a cow mortality rate of zero, and is based on calving at regular intervals and producing the same amount of milk irrespective of the age of the cows. Annual reproduction of cattle is based on the rate of one calf for every two adult cows, in addition to fixed amounts of 'dairy fat' and cheese per cow per year. The total amount of 'dairy fat' and cheese production over the ten-year period was calculated and converted into its corresponding value equivalence expressed in silver, using the exchange rate of 10 sila of dairy fat or 150 sila of cheese for one shekel of silver (ibid, pp. 97-102).

\section{ACCOUNTING AND ACCOUNTABILITY IN ANCIENT EGYPT}

The royal palace and the temple constituted two influential institutions in the economy and society of ancient Egypt (Warburton, 1997). Therefore, we shall organize our description of practices of accounting in this setting by distinguishing between such settings and other domains of economic and social life.

\section{The Royal Palace and the Temple}

Sparse evidence remains from whatever records and accounting books were kept for the royal palaces throughout ancient Egyptian history. The most complete and detailed evidence dates to the Middle Kingdom in the form of summary accounts of a royal visit to Thebes from the Thirteenth Dynasty which were examined by Ezzamel (2002b). The royal entourage included the Pharaoh, his family, immediate dependents, the Vizier, high officials, and courtiers covering the treasury, the priesthood and the military. The papyri included (i) statements of account, covering the provisions, special deliveries, remainders, balances and surplus; (ii) orders of provision earmarked for specific individuals; (iii) expenditure of valuable commodities as lists of offerings; and (iv) official reports and documents, detailing specific 
items received in the presence of witnesses. What the accounts reveal is an intricate web of redistribution that co-ordinated perfectly the inflows and outflows of commodities. For example, the accounts were kept on a daily basis, with separate columns for each type of commodity. Furthermore, the accounts almost exactly matched supplies and provisions for every day. A recurrent daily balance of bread was kept by the scribes as a safety-net in case supplies on a particular day fell short of requirements; whereas for more fresh and perishable goods, such as vegetables, supply exactly matched requirements without balances being kept. Also, special requirements on a particular day were accounted for by the scribes via a new entry called 'due today' to trace this special requirement.

Ezzamel (2002b) concludes his discussion by making a number of remarks on the overall significance of these daily summary accounts. First, they established, reaffirmed and reproduced social order by observing a particular order of the entries that reflected social status and power. Secondly, they linked sources of revenues and provisions to specific institutions which reflected the dependency of the state on these institutions. Thirdly, the precisely determined rations of provisions reinforced dependency relations reflected in the social and political status of the recipient.

The importance of temples in ancient Egypt came from their imposing role in the ritual of death that characterized such society (Assmann, 2002; 19??). Therefore, it is not surprising that, among surviving evidence, several fascinating papyri and inscriptions on stone relate to temple activities and the preservation of the cult of dead Pharaohs and important officials. Ezzamel (2005, forthcoming) examines a set of documents from the Old Kingdom relating to the temple of King Néferirkarê-Kakai (Fifth Dynasty). The documents in the papyri contain lists of attendance and allocation of work duties on a daily basis, along with daily and monthly accounts detailing collection of goods and their distribution and inventory lists of equipment and various items. In the case of inventory lists, a grid-structure is used whereby items are grouped within specific categories that are organised under a hierarchy of three levels of classification, reflecting gradual finer details for each item listed. At the end of its period of work (usually two months), the departing phyle (gang/team) delivered the equipment to the stores and the scribe noted the exact state of each equipment and the repairs required. A mixture of red and black ink was used to differentiate the entries and the columns of the inventory list to enhance visibility. Lines were drawn by the inspectors to indicate that inspection took place. The departing phyle and the incoming phyle each prepared a report indicating the state of the equipment they are leaving behind or receiving upon arrival for their shift. The temple income accounts again used a grid structure and black and red inks to note for every day of the month deliveries, by name of porter and source, remainder, and the place to which these deliveries are sent as provisions.

In the case of inventory lists, recording items using a combination of black and red ink in a tabular format (organisational visibility), and the enumeration of quantities of items and the classification taxonomy (technical visibility) made it easy for the scribe to signal damaged items as well as the nature of the damage. Apart from legitimising the role of the scribes, this made it possible to both trace responsibility for damage to the appropriate (departing) phyle and to plan the repair of damaged items in time for the arrival of the new phyle. In the monthly income accounts of the temple, the elaborate distributive system revealed, based on 
precise rations, the pattern of deliveries and distributions, with the scribes being able to trace a particular delivery to its exact amount and original source with such dependency visibility enshrined into accounting entries. Through the use of a grid system and the judicious combination of black and red ink the scribe could differentiate between amounts due as revenue, actual quantities delivered and remaining balances. Ezzamel argues that accounting played a key role in determining the precise allocations of provisions for every member of temple staff and recording the delivery of these provisions. Crops were collected, in the form of carefully assessed tax or impost, and transported to the state granaries where they were stored. Provisions, or wages, were issued from these granaries and distributed to the appropriate individuals according to precisely determined rations that reflected status. Ezzamel also provided a reconstruction of the network of institutions that were involved in this complicated chain of provision and distribution, thereby emphasising the dependency relationship that bonded all such institutions together.

Further evidence on accounting for the temple comes from the Middle Kingdom (Ezzamel, 2002b). The evidence is in the form of ten contracts intended to be executed after the death of a high ranking official. Ezzamel shows how accounting practices underpinned the contractual arrangements of the dead that were finalised in their life times. The intervention of accounting was not simply restricted to the writing of a will; it also involved determining the precise amounts of offerings to be made of each type of commodity. Rather than being enforced by law, these contracts were sanctioned by social norms as well as incentives built into the contracts to motivate the priests entrusted with the execution of the contracts with a view of ensuring that the measured giving on behalf of the dead is observed.

\section{Other Domains of Public and Private Life}

In an economy as highly centralized as that of ancient Egypt, the importance of taxation looms large (Wilson, 1949). The relative importance of the state domain compared to the private domain in ancient Egypt is still widely debated in the literature. At one extreme, there is the view that the Pharaoh owned most things, baring little else beyond individual possessions, securing the services of his subjects to work in this domain as a royal prerogative in return for provisions (Wilson, 1949). Others, however, point to strong evidence that indicates significant private ownership, such as land, farms, houses, and small manufactury, such as flax-textiles (Quirke, 1990). Either way, tax revenue formed a significant part of the state revenues, and its assessment, collection and redistribution was a major occupation for scribes and other state officials. (see also Ezzamel, 1997).

While the genesis of levying and collecting tax goes back to pre-what has now been dubbed as Dynasty Zero (3300 B.C. onwards; Davies and Friedman, 1998), work on ancient Egyptian taxation in the accounting literature has so far focused on the Middle Kingdom and beyond (2050 BC onwards). Ezzamel (2002b) examined a tax-assessor's journal dating back to the end of the Twelfth (1991-1778 BC) or the beginning of the Thirteenth Dynasty (1778-1625 BC). The papyrus is badly damaged and as a result it contains no information on tax calculation, but it shows details of the steps taken by the scribe to assess tax. Initially, the land to be taxed was surveyed and the tax crop was measured. The tax scribe was accompanied by the following, each entrusted with a specific responsibility: the clerk of land (the custodian of 
the regulations of land registry), the envoy of the steward who took internal measures of both land and crop on behalf of the steward, the stretcher of the cord, and the holder of the cords who both took measures of the standing crop. The same paper reviews additional evidence pertaining to the levying and collection of tax from the Twelfth Dynasty, where specific individuals were charged with the responsibility of collecting given amounts of tax (wheat, corn, barley, bread, ducks and geese) levied as dues on the Pharaoh's subjects.

Further light is shed on taxation practices in Ezzamel (2002a) relating to the New Kingdom. The paper traces what it terms the 'cycle of taxation" "which involves the definition of taxable entities, the estimation, final assessment, collection, transportation and storage of taxes" (ibid, p. 17). Tax subjects were the temples, state officials (whose taxation was exceptional, because tax was typically levied on physical produce but not on (mental) administrative and scribal activities), Khato-lands (lands earmarked to supply revenues to the Crown), and ordinary people. Ezzamel examines evidence that demonstrates how the remaining parts of the cycle of taxation were carried out. This entailed the scribes measuring the lands whose crop was to be taxed, converting the size of a given plot of land into a taxable equivalent crop using some common denominator in the form of a capacity measure. Any accounting for such tax activities, as well as the cycle of redistribution, from collection and storing to redistribution, would have required some knowledge of the relevant population in order for the resources collected and redistributed to be carefully balanced. The granaries also functioned as an insurance against unplanned shortage in supplies caused by natural phenomena (e.g. low Nile inundation) or miscalculation of needs. The evidence also suggests that tax assessment varied in a strict linear proportionality to two parameters: the measured area of the land, and its fertility assessed through rates (multipliers) varying between 5, $71 / 2$, and 10, the higher the multiplier the more fertile the land is judged to be.

Once tax was assessed and collected, it was transported to the state granaries, and this process was organized and documented carefully by the scribes. For every case of tax collection/delivery, the scribes recorded the date and location of the activity, the precise threshing floor for the crops, the exact amount of tax whose collection was entrusted to an official/scribe, the names of the ship captains that transported the tax collected, the amount of tax carried by each boat, the rations allocated out of the tax collected for the consumption of the crew of each ship, and finally accounting for the delivery of tax collected to the state granaries and the deficit remaining. A summary section at the end of each document acted as a check to ensure that the detailed entries entered earlier add up to the expected total. Tax assessment was quantified using capacity measures, such as the khar, oipe, and hin. Ezzamel also discusses the details of a case of tax defalcation that went on undetected for nine years until it was ultimately uncovered, thanks to the detailed and careful recording of the amounts of tax due to state granaries. This evidence testifies to the presence of an ancient system of human accountability, as expected assessments and deliveries of tax were compared against actual deliveries, with responsibility being traceable to specific dates, locations and individuals. 


\section{Bakeries}

Ezzamel (1997) used some pictorial evidence as well as a number of detailed entries in accounts to forge a preliminary picture of accounting for the bakeries (with similar conclusions applying to breweries). He constructed a cycle of ancient accountability that began with the input of grain transferred from the granaries to the bakery, and progressed to account for the different processes of baking. This involved determining allowances for natural baking loss, weight conversion rates to calculate number of loaves of a given weight/size expected of a specific input, dilution (baking/cooking) ratios to control for the proportions of water and flower in making the dough, equivalent weight of baked bread transferred from the bakery to the storehouse, and a final comparison of numbers of breads of given weights and dilution actually produced against expected output from the input of grain. The accounts also traced targets and actual output per individual baker every day. The system of accounting used entailed weighing, pure counting, a measure of quantity equivalence, a quality adjustment (the baking ratio), predetermined natural loss in baking, output targets, measures of actual output, and calculation and reporting of variances between targets and actual achievements reported on a daily basis. All these details made possible a form of control and human accountability that visualized the performance of individuals and institutions.

\section{Royal Construction Projects/Workshops}

The most detailed evidence available from ancient Egypt comes from the latter part of the Middle Kingdom, and in particular from the reign of Senusret III (Twelfth Dynasty). This particular era witnessed a major expansion in administrative titles and practices, and also crucially in record keeping. A remarkable number of papyri survived from that era, covering a variety of activities relating to construction projects for the Pharaoh and also the activities of royal workshops for making and repairing items such as tools, boats and building material. Ezzamel (2004a) examined this evidence within the context of ancient work organisation. His analysis shows how for royal projects daily attendance lists were kept, which detailed names, titles, days spent by each workmen on project work, days of absence, days in transit (between projects) and total days, payroll or provision allocations per day, tasks (work targets) allocated to workmen converted into equivalent man-days, work completed and work remainder. Workshop accounts included details of items delivered to be worked on, either for a whole job or on a daily basis, converted in their diversity into a single common denominator as money of account (deben), amount of work completed and the remainder. What this extremely rich evidence reveals is full system of ancient human accountability at work based on careful division of labour, allocation of predetermined work targets, regular reporting on actual achievements, and the remainder of work to be completed. The evidence also reveals a finely tuned reward structure (in the form of fixed provisions) which took careful account of the rank of every category of work, hierarchical position, or responsibility. Ezzamel (2004: 530-531) however notes:

"The notion of time emphasized in these practices was not 'timed labour', the concept associated with industrial capitalism, but rather was much closer to 'task orientation'... In this emphasis, concern was focused upon ensuring that a particular task was completed, 
rather than being obsessed with meeting time targets, such as those enshrined in modern time-and-motion studies."

\section{Accounting for the Private Domain}

The accounting literature dealing with the private domain in ancient Egypt is remarkably sparse. In part, this is because much of the activities of ancient Egypt centered on the state, its temples, and its various establishments. Another reason is that a significant amount of inscriptions focused upon the afterlife (or the other life, as the ancient Egyptians would prefer to call it). Matters of this life were relatively much less important than those of the other life, hence less attention to inscriptions of activities in this life. Another main problem is caused by the fact that, unlike inscriptions for the state and death usually made on stone, much of the evidence relating to private transactions was recorded on papyri and ostraca (shreds of pottery); the first is easily perishable unless kept in dry places, and the second probably reused to write new transactions, hence obliterating evidence of earlier transactions. However, there is still a reasonable amount of evidence on the private domain which has hardly been exploited.

Janssen (1975) collated the prices of a large number of commodities covering a period of approximately 150 years, in the necropolis village of Deir El-Medina during the New Kingdom, but his focus has been in the main upon documenting and comparing prices rather than being concerned with accounting transactions per se. Ezzamel and Hoskin (2002) examined the development of monies of account in ancient Egypt and explored how it, along with accounting technology, were used by the ancient scribes to constitute value reciprocity. They also reviewed a number of market transactions derived from Janssen (1975) and noted the emphasis upon ensuring that the commodities exchanging hands were of equivalent value, in terms of money of account. This, they argue, was a fundamental requirement in order to secure the mutual satisfaction of both parties to a transaction.

Ezzamel and Hoskin (2002) examined some transactions that involved a break down of the 'cost' of each of the various items that made a bigger item, say the legs, head, and body of a bed, along with the 'cost' of decorating each part. The evidence stops short of explaining what these breakdowns were used for, perhaps other than the impression that it was the seller's way of justifying the full price of the complete item (a bed in this case) or in order for the buyer to have the option of having some items, but not others provided. Some other transactions revealed the payment for a share of an object (an ox), opening up the possibility that, through the use of money of account, the ownership of an expensive item could be spread among a few owners. They argued that the development of 'monies of account', as non-coinage money, such as the deben, or the khar as a supplement to accounting, in the form of a numeraire resulted in further developments in the role of accounting that would not have been possible without the intervention of money and its power; in particular the role of money as a constructor of value and in underpinning the notion of value, measure-to-measure, reciprocity. Finally, Ezzamel and Hoskin explore the impact of the emergence of coinage during the reign of the Twenty Ninth Dynasty (398-378 .C.) in ancient Egypt, whereby focus in exchange shifted from detailing the precise payments to an indication that the vendor was 'satisfied' with what s/he received. The major shift here is in terms of substituting value reciprocity under coinage for object reciprocity under non-coinage money; hence, reciprocity 
became vested in pure exchange lying beyond the objects rendered equivalent. Ezzamel and Hoskin (p. 358) sum up this crucial difference caused by the emergence of coinage; thus:

"No money imposed a new kind of differentiation, between the pure buyer (exchanging money) and the pure vendor (exchanging the commodity). Even where there was an old-style exchange of commodities via the medium of money, this was now being seen (as we still see it today) as two transactions. This change launched a new power for money, which can now circulate, which was supplemented further in the Middle Ages with the invention of the first paper money instruments."

Ezzamel (2002c) analyzed a set of business letters and accounts belonging to a farmer from the Middle Kingdom, the only surviving evidence of household and farm accounts from ancient Egypt. The household part of the letters and accounts deals with a new set of provisions for every member of the household, which have been reduced substantially following a drop in the level of the Nile. Not only did the rations ensure the careful matching of what the head of the family provided for consumption with the needs of every member of the family, they also reflected and reproduced the standing in which each member was held. The second part of the letters and accounts relates specifically to farm activities, including cultivation of own land, renting and cultivating additional land, managing the herd and their fodder, some agricultural produce, and private debt and its collection. As in previous evidence examined earlier, a variety of accounting measures were employed. Reasonably homogeneous items (for example, bundles of flax) were simply counted and recorded as identities, as the counted items in themselves carried implicit values through which equivalence within a given category of items could be observed. Where items were far less homogenous, equivalence was secured via the specification of precise weights/volume or via the use of more direct monies of account, such as the deben or the khar.

\section{DISCUSSION AND CONCLUSIONS}

The above overview of accounting practices and accountability in Mesopotamia and ancient Egypt reveal a wealth of insights. Far from being a rudimentary technology, accounting practices in both ancient civilizations displayed remarkable levels of detail and sophistication. Accounting inscriptions functioned in a multitude of settings, ranging from the private sphere to the public sphere, and from the activities of the living to the affairs of the dead. Accounting developed an apparatus that entailed a careful recording system, whereby entries emphasized the amounts involved, using either counting or valuation through monies of account, persons/institutions involved, location, and dates. In the case of transactions between individuals, the entries clarified the debits and credits involved. In the case of accounting for human activities, such as tool making, building projects, querying activities, and animal husbandry, targets were set in advance, natural losses in conversion were accounted for, and actual achievements were compared against targets, with the balance outstanding shown clearly. Hence, these accounting inscriptions provided the basic requirements for an ancient temporal and spatial system of human accountability to function. And just like any system of human accountability of contemporary times, these ancient systems were also prone to human manipulation, as in the case of tax defalcation reported in ancient Egypt. Once systems of accountability are imposed upon recalcitrant subjects, possibilities for gaming the system abound. 
Rather than simply attend to the basic requirements of stewardship accounting, these ancient accounting practices went far beyond that by developing spatially and temporally designated entries that tracked and assessed human performance in some considerable detail. This system of human accountability was contextually dependent. Thus, at the level of the accountability of an individual to another individual, say in the case of a semi-barter transaction, the locus of responsibility were the two transacting parties, in the presence of the scribe who made the accounting entries. While such entries could not be taken to be equivalent to a legal text, nonetheless the intervention of the scribe and the technology of accounting mediated this relationship of accountability. This mediation was one of technical, expert accounting knowledge, coming as it did between the transacting parties to always quantify, and in many cases value, the items exchanged, thereby ensuring an element of economic reciprocity that at once emphasized the account ability of each party to the other. While this accountability was in the main vested in the process through which the transactions were inscribed (the intervention of accounting technology and the scribe as its artisan), in other cases it was buttressed by social norms, as in the case of inciting other individuals to be watchful of the party entrusted to perform certain tasks (e.g. a priest contracted to keep the cult of a dead person for a fee).

Accountability was also observed at the level of the individual-state and state-individual. At the individual-state level, the accounting entries and processes ensured that accountability could be exercised via the specification of prior targets, the allocation of tasks to individuals, the measurement of actual performance, the identification of differences between targets and actual achievements, and the reporting of action taken. This system of accountability fully squares the circle, and provides a complete cycle of human accountability. Frequently, this accountability system was further buttressed by a system of two-way reporting, whereby the report by each party provided formal proof of the extent of their own accountability, thereby ensuring that their accountability was not confounded by elements outside their own control. The responsibility of the individual towards the state was therefore enshrined in a sense of duty to perform a task well and to meet the targets set, with accounting entries visualizing the extent to which the individual attended to the level of accountability expected by the state.

In the case of the state-individual level of accountability, the state was entrusted with the responsibility of honoring its commitments to the individuals. In a redistributive economy such as that of ancient Egypt, and even in the less centrally driven economy of Mesopotamia, this responsibility entailed providing at least adequate provisions to ensure the survival of the population. In economically prosperous times, more was expected beyond sheer survival, as evidenced by accounting entries detailing the distribution of foodstuffs and drinks in state festivals. Accounting entries served to demonstrate to all concerned how the state met its responsibility towards its subjects, again visualizing precisely how the needs of each individual were accounted for.

These forms of accountability at all the levels discussed above were always underpinned by social and religious norms and beliefs. Not only were state sanctions the source of compliance, ethical and religious arguments had a powerful role in shaping accountability. In the case of ancient Egypt, observing Maat was a quality aspired to by all Egyptians, the kings included. To observe Maat meant to preserve justice and order on earth and in the cosmos. 
Accounting practices visualized how Maat was observed, by demonstrating that economic reciprocity underpinned exchange between individuals, and by showing how the individual attended to his/her responsibilities towards the state and the state towards the individual. Similar social forces seem to have also been at work in the case of Mesopotamia. In both ancient civilizations, in accounting for the the cult of the dead, or for the relationship between the living and the gods (cosmos), a different kind of reciprocity was at play, a reciprocity that did not always match the two sides of a transaction on the basis of the purely economical, but one that emphasized the social and the ceremonial. The very notion of what we today understand by 'measure for measure' was conspicuously absent in such activities, for how could the gratitude felt by a nation towards her gods, or a humble subject towards a king, be quantified and precisely matched? So, in giving for the gods, the magnitude of giving, as quantified and valued through the accounting craft, reflected the status of the gods and kings; the more the giving the more prestige and status.

In these ancient civilizations we are therefore confronted with a set of accounting practices that played both on the economic impulse of individual transactors, by emphasizing the 'measure-for-measure' mentality via economic equivalence in exchange, and on the social/ceremonial tendencies that were particularly prevalent in ancient cultures. Accounting for accountability in this ancient world was therefore invested in all aspects of the economic, the spiritual, and the ceremonial.

These observations have powerful implications for the theorizing of accounting. Rather than being confronted with an ancient inadequacy manifest in rudimentary systems of accountability, here we encounter developed systems that were fully embedded in the relevant socio-political, religious and economic contexts. These systems functioned in ways that fundamentally underpinned the achievements of the civilizations of Mesopotamia and ancient Egypt. They played key roles in facilitating economic and social order, at the levels of the individual, the state, and the cosmos. In this sense, accounting from its genesis has been a powerful mediating institution among individuals, organizations and society. This mediating role remains at the centre of how accounting functions in contemporary organizations and society.

What of the way forward? It is evident from the above overview that so many exciting insights have emerged concerning the role of accounting practices in developing systems of ancient accountability. At the same time, we should be aware that for all richness and scholarly endeavour, the studies reviewed above have only scratched the surface of an enormous area of research. Future research can progress on a number of fronts. First, contemporary scholars researching ancient accounting practices would benefit greatly from confronting more directly some of the challenges posed by the nature of the data (in terms of the major lacunae characterizing much of the data), the problems caused by translation and inappropriateness of contemporary languages, the lack of sufficient context within which accounting practices were undertaken, and gaining a sensible understanding of these contexts in their remoteness as viewed from the vintage of the present. Some of these problems may be un-surmountable, but at the very least this should be acknowledged from the outset. It would also be helpful to capitalize on the expertise of scholars of ancient history in dealing with these problems. 
Second, much of the research reviewed above, particularly in the case of ancient Egypt, has been dealing with the public domain of society. While more research on this sphere is still needed, the need is even much greater for a more systematic examination of the role of accounting practices on the lives of ordinary individuals and communities. We know precious little about how accounting practices in the ancient world impacted on the lives of workers, peasants, private activities, and the household, and more research in these areas would further our understanding of the roles of accounting in society.

Third, of necessity, much of the extant literature has tended to focus on providing a detailed analysis of accounting practices in particular organizations/activities within specific historical episodes. This clearly has allowed researchers to focus on individual issues in great detail. Missing in this analysis is an appreciation of the trajectory of accounting practices across different historical episodes; a project that is perhaps more suited to research monographs and books rather than journal articles. Such macroscopic analysis, while perhaps short on the fine detail found in specific journal articles, would offer a unique opportunity to chart changes in accounting practices across time and space.

Fourth, a more direct approach to examining the implications of ancient accounting practices for the theorizing of accounting still needs to go much beyond what has been attempted so far. For example, to the extent that ancient accounting practices are understood to be more invested in notions of reciprocity that emphasize the spiritual, religious, and ceremonial at the expense of the economic, what implications does this understanding have on the way we theorize contemporary accounting? Similarly, what lessons, if any, do we learn from analyzing accounting practices that are not based on any explicit notion of money, of whatever form, in our effort to theorize accounting? Also, have we fully appreciated the impact of the invention of monies of account and writing on accounting? What are the major differences in the implications for the development of accounting, if any, does the shift from money of account to monetarism has? These, and numerous other questions, await the efforts and endeavours of future researchers. 


\section{REFERENCES}

Assmann, J. (2002), The Mind of Egypt, New York: Metropolitan Books.

Ball, T. (1995), Reappraising Political Theory: Revisionist Studies in the History of Political Thought, Oxford: Oxford University Press.

Barry, N.P. (2000), An Introduction to Modern Political Theory, $4^{\text {th }}$ Edition. New York: St. Martin's.

Chatfield, M. (1977), A History of Accounting Thought, (Huntington, NY: Krieger Publishing Company).

Dalton, G. (1968), "Introduction", in G. Dalton (ed.), Primitive, Archaic and Modern Economies - Essays of Karl Polanyi, Garden City, NY: Doubleday Anchor. Pp. 27-58.

Eisenstadt, S.N. (1969), The Political Systems of Empire: the Rise and Fall of the Historical Bureaucratic Societies, Glencoe, NY: Free Press.

d'Encausse, H.C. and Schram. S.R. (1969), Marxism and Asia, London: The Penguin Press.

Ezzamel, M. (1994), "The Emergence of the 'Accountant' in the Institutions of Ancient Egypt”, Management Accounting Research, Vol. 5, pp. 221-246.

Ezzamel, M. (1997), “Accounting, Control and Accountability: Preliminary Evidence from Ancient Egypt", Critical Perspectives on Accounting, Vol. 8, pp. 563-601.

Ezzamel, M. (2002a), "Accounting Working for the State: Tax Assessment and Collection during the New Kingdom, Ancient Egypt", Accounting and Business Research, Vol. 32, No. 1, pp. 17-39.

Ezzamel, M. (2002b), “Accounting and Redistribution: the Palace and Mortuary Cult in the Middle Kingdom, Ancient Egypt”, Accounting Historians Journal, Vol. 29, No. 1, pp. 61103.

Ezzamel, M. (2002c), "Accounting for Private Estates and the Household in the Twentieth Century B.C. Middle Kingdom, Ancient Egypt”, Abacus, Vol. 38, No. 2, pp. 235-262.

Ezzamel, M. (2004), "Work Organization in the Middle Kingdom, Ancient Egypt", Organization, Vol. 11, No. 4, pp. 497-537.

Ezzamel, M. (forthcoming), "Accounting for the Practices of Funerary Temples: the Intertwining of the Sacred and the Profane", Accounting and Business Research. 
Ezzamel, M. and Hoskin, K. (2002), "Retheorizing Accounting, Writing and Money with Evidence from Mesopotamia and Ancient Egypt", Critical Perspectives on Accounting, Vol. 13, pp. 333-367.

Ezzamel. M. and Willmott, H. (2004), "Rethinking Strategy: Contemporary Perspectives and Debates", European Management Review. Vol.1 (1): 43-48.

Finkelstein, J.J., (1968), "An Old Babylonian Herding Contract and Gen 31:38f.," Journal of the American Oriental Society, Vol. 88: 30-36.

Finley, M.I. (1992), The Ancient Economy: London: Penguin Books.

Grimal, N. (1992), A History of ancient Egypt, Translated by I. Shaw, Oxford: Blackwell.

Goetze, A.(1956), The Laws of Eshnunna, The Annual of the American Schools of Oriental Research, Vol. 31: 1951-1952.

Gunwardana, R.A.L.H. (1981), "Social Functions and Political Power: A Case Study of State Formation in Irrigation society", in H.M.J. Claessen and P. Skalnik (eds.), The Study of the State, pp. 133-154, The Hague: New Babylon Studies in Social Sciences 35.

Harris, R. (1961), "On the Process of Secularization Under Hammurapi", Journal of Cuneiform Studies, Vol. 14: 117-122.

James, T.G.H. (1968), “An Early Middle Kingdom Account”, Journal of Egyptian Archaeology, Vol. 54: 51-56.

Janssen, J.J. (1975), Commodity Prices from the Ramessid Period, Leiden: E.J. Brill.

Janssen, R.M. and Janssen, J.J. (1990), Growing Up in Ancient Egypt, London: The Rubicon Press.

Keister, O.R. (1963), Commercial Record-Keeping in Ancient Mesopotamia, The Accounting Review, Vol. 38: 371-376.

Kemp, B. (1989), Ancient Egypt: Anatomy of a Civilization, London: Routledge.

Lau, R.J. (1906), Old Babilonian Temple Records (New York: Columbia University Press).

Leemans, W.F. (1960), Foreign Trade in the Old Babylonian Period, Leiden: E.J. Brill.

Littleton, A.C. (1968), The Antecedents of Double-Entry Bookkeeping, in Chatfield, M. (ed.), Contemporary Studies in the Evolution of Accounting Thought, Belmont, CA: Dickenson Publishing Company Inc.: 48-56. 
Maekawa, K. (1990), "Cultivation methods in the Ur-III Period", Bulletin on Sumerian Agriculture, Vol. 5: 115-123.

Maisels, C.K. (1993), The Emergence of Civilization, London: Routledge.

Mattessich, R. (1987), "Prehistoric Accounting and the Problem of Representation: on Recent Archaeological Evidence of the Middle-East from 8000 B.C. to 3000 B.C.", Accounting Historians Journal, Vol. 14, No. 2, Fall, pp. 72-91.

Mattessich, R. (1989), "Accounting and the Input-Output Principle in the Ancient and Prehistoric World”, Abacus, Vol. 25, No. 2, pp. 74-84.

Mattessich, R. (1991), "Counting, Accounting, and the Input-Output Principle: Recent Archaeological Evidence Revising our View on the Evolution of Early Record Keeping", in O. F. Graves (ed.), The Costing Heritage - Studies in Honor of S. Paul Garner, Harrisonburg, VA: Academy of Accounting Historians, Monograph No. 6, pp. 25-49.

Mattessich, R. (1994), "Archaeology of Accounting and Schmandt-Besserat's Contribution", Accounting, Business and Financial History, Vol. 4, No. 1, pp. 5-28.

Mattessich, R. (1998), "Recent Insights into Mesopotamian Accounting of the $3^{\text {rd }}$ Millennium B.C. - Successor to Token Accounting", Accounting Historians Journal, Vol. 25, No. 1, June, pp. 1-27.

Mattessich, R. (1998), "Follow-Up to: 'Recent Insights into Mesopotamian Accounting of the $3^{\text {rd }}$ Millennium B.C.': Correction to Table 1", Accounting Historians Journal, Vol. 25, No. 2, December, pp. 147-149.

Mattessich, R. (2000), The Beginnings of Accounting and Accounting Thought -Accounting Practice in the Middle East (8000 B.C. to 2000 B.C.) and Accounting Thought in Inida (300 B.C. and the Middle Ages), (New York: Garland).

Myhrman, D.W. (1910), Sumerian Administrative Documents Dated in the Reigns of the Kings of the Second Dynasty of Ur from the Temple Archives of Nippur Preserved in Philadelphia, (Philadelphia: H.V.Hilprecht).

Nesbit, W.M. (1914), Sumerian Records from Drehem, (New York: Columbia University Press).

Nissen, H.J., Damerow, P. and Englund, R.K. (1993), Archaic Bookkeeping, translated by P. Larsen, Chicago: The University of Chicago Press.

Oppenheim, A.L. (1964), Ancient Mesopotamia: Portrait of a Dead Civilization, Chicago: The University of Chicago Press. 
Oppenheim, A.L. (1954), "The Seafaring Merchants of Ur", Journal of the American Oriental Society, Vol. 74: 6-17.

Polanyi, K. (1957), "Trade and Market" in K. Polanyi, C.M. Arsenberg and H.W. Pearson (eds.), Trade and Market in the Early Empires - Economies in History and Theory, New York: The Free Press.

Polanyi, K. (1977), The Livelihood of Man, New York: Academic Press.

Postgate, J.N. (1992), Early Mesopotamia, London: Routledge.

Powell, M.A. (1981), 'Three Problems in the History of Cuneiform Writing: Origins, Direction of Script, Literacy', Visible Language, Vol. 15, No.4: 419-430.

Powell, M.A. (1984), "Late Babylonian Surface Mensuration”, Archiv für Orientforschung, Vol. 31: 32-66.

Pritchard, J.B. (1975), The Ancient Near East (Princeton: Princeton University Press). Two Volumes.

Quirke, S. (1990), The Administration of Egypt in the Late Middle Kingdom: The Hieratic Documents, New Malden, Surrey: SIA Publishing.

Renger, J. (1984), "Patterns of Non-Institutional Trade and Non-Commercial Exchange in Ancient Mesopotamia at the Beginning of the Second Millennium B.C.", in A. Archi (ed.), Circulation of Goods in Non-Palatial Context in the Ancient Near East, Roma: Edizioni Dell'Ateneo, pp. 31-123.

Rivero Menéndez, M.R. (2004), La Formación de los Registros Contables en Mesopotamia, (Madrid: Dimasoft).

Schmandt-Besserat, D. (1977), "An Archaic Recording System and the Origin of Writing", Syro-Mesopotamian Studies, Vol. 1, No. 2, pp. 1-32.

Schmandt-Besserat, D. (1978), "The Earliest Precursor of Writing”, Scientific American, Vol. 238, No. 6, pp. 50-58.

Schmandt-Besserat, D. (1979), "Reckoning Before Writing”, Archaeology, Vol. 32, No. 3, pp. 23-31.

Schmandt-Besserat, D. (1980), "The Envelops that bear the First Writing", Technology and Culture, Vol. 21, No. 3, pp. 357-385.

Schmandt-Besserat, D. (1981a), "Tablets and Tokens: A Re-examination of the So-called 'Numerical Tablets"', Visible Language, Vol. 15, pp. 321-344. 
Schmandt-Besarat, D. (1981b), "Decipherment of the Earliest Tablets", Science, Vol. 211, pp. 283-285.

Schmandt-Besarat, D. (1982), "The Emergence of Recording", The American Anthropologist, Vol. 84: 871-878.

Schmandt-Besserat, D. (1983), "Tokens and Counting", Biblical Archeologist, Spring, pp. 117-120.

Schmandt-Besserat, D. (1984a), "The Emergence of Recording", American Anthropologist, Vol. 84, pp. 871-878.

Schmandt-Besserat, D. (1984b), "Before Numerals", Visible Language, Vol. 15, No. 1, pp. 48-59.

Schmandt-Besserat, D. (1986a), "The Origins of Writing - An Archeologist's Perspective", Written Communication, Vol. 3, No. 1, January, pp. 31-45.

Schmandt-Besserat, D. (1986b), "The Precursor to Numerals and Writing", Archeology, November-December, pp. 32-38.

Schmandt-Besserat, D. (1992), Before Writing, Volume I: From Counting to Cuneiform: Austin: University of Texas Press.

Schmandt-Besserat, D. (1997), The History of Counting, New York: Morrow, Junior Books.

Schenkel, W. (1978), Die Bewässerungsrevolution im alten Ägypten, Mainz: S DAIK.

Snell, D.C. (1997), Life in the Ancient Near East, New Haven: Yale University Press.

Spalinger, A. (1986), Baking During the Reign of Seti I", Bulletin De Institut Francais D’Archeologie Orientale, Vol. 86, pp. 307-352.

Stevelinck, E. (1973), La Comptabilité à Travers les Âges, Bruxelles: Bibliothèque Royal Albert $1^{\mathrm{er}}$.

Stol, M. (1985), "Fragment of a Herding Contract", in Miscellanea Babylonica (Editions Recherche sur les Civilisations: Paris).

Trigger, B.G. (1993), Early Civilizations, Cairo: The American University Press.

Warburton, D.A. (1997), State and Economy in Ancient Egypt, Vandenhoeck \& Ruprecht Göttingen: University Press Fribourg Switzerland.

Wilkinson, R.D. (1994), Symbol and Magic in Egyptian Art, London: Thames and Hudson.

Wittfogel, K. (1963), Oriental Despotism: A Comparative Study of Total Power, New Haven: Yale University Press. 
NOTAS

בx


NOTAS 